\title{
A Case Studt of an Intervention Program for Students with Dyslexa in A primary School in the $\cup \mathcal{A E}$
}

\author{
Elazab Mohamed Elazab Elshazly \\ Special Education Department \\ College of Education \\ United Arab Emirates University
}

\begin{abstract}
7 his paper aims to explore the effect of an iPad program and the usage of different downloaded apps to help students with dyslexia on reading, writing and spelling abilities in two classes of an open elementary school. The investigation takes after a blended strategy approach (survey; face to face interviews; pre-posttests). Twenty (20) third graders male students with dyslexia, going to English as a Foreign Language classes were the members of the examination. Students' implementation on spelling, reading and writing abilities were tried after trained through an iPad intercession program with multisensory applications. The experimental group's implementation (10 students with dyslexia) was contrasted with the control group's (10 students with dyslexia) educated through non-PC based, techniques. A pre-appraisal test was directed for assessing the reading, spelling and writing abilities of the two gatherings of understudies before the mediation. After eight (8) weeks, both groups were involved in post-tests for evaluating their performance on reading, spelling and writing skills. The examination found that the students' with dyslexia aptitudes were enhanced after the iPad intercession program rather than the students taught through standard strategies.
\end{abstract}

Keywords: iPad, EFL, dyslexia, multi-sensory approach, iPad applications

\section{Problem}

Society acknowledges reading, writing, and spelling as essential skills for learning things such as new technology (Lundberg, et.al, 2010). A large number of young students with dyslexia find these essential skills very difficult to grasp which affects their learning ability (Mullis, Martin, Kennedy and Foy, 
2007). Research studies have shown that students with dyslexia appear less competent in English as a Foreign Language (EFL) as against their peers, unless they received additional support (Fawcett and Nicolson, 1994; Beech \& Singleton, 1997).

Various diverse learning difficulties affect school students with dyslexia and cause their failure from lack of basic skills, which pedagogues have to address in the classroom (Bramlett, Murphy, Johnson and Wallingsford, 2002). Therefore, it is important for educators to be well equipped for struggling readers, writers, and spellers affected by dyslexia. Although knowledge and support are available in current research regarding appropriate measures, there is however a need for innovative techniques and appropriate interventions to suit individual cases.

\section{Motivation}

The author of this study has 22 years' experience as a teacher of English language in both public and private schools, serving students of all grades. He observed that students with dyslexia appear to be less able to read, write, and spell in English language in contrast to their peers, unless he gave them additional lessons. This discrepancy increased during the course of their academic year which jeopardizes the chances of students with dyslexia of succeeding in higher education. A large percentage of students with dyslexia' in the UAE for instance do not grasp the basic skills in English or Arabic, their first language. This anomaly motivated the author of this study to develop an innovative intervention program.

\section{The construction of the iPad intervention program}

The applications coordinated inside the particular iPad program were developed by mulling over the helpful data by the students' with dyslexia instructors. The researcher conveyed a poll to the educators to distinguish the level of the students' with dyslexia in spelling, reading and writing; what they required; what they needed; how they appreciated learning. 
A sample of 17 teachers responded to the questionnaire (Table 1). Table 1 points to the questionnaire and what are the responses of teachers toward the most common skills that the students with dyslexia need to acquire; the programs they need; and the applications that might help them improve their spelling, reading and writing skills in EFL.

Table 1: Information from the teachers' questionnaire

\begin{tabular}{|c|c|c|c|c|}
\hline \multicolumn{2}{|c|}{ Gender } & Years of & \multicolumn{2}{|c|}{ Teachers' views } \\
\hline Male & Femal & Most & Teaching methods & Technology \\
\hline $\mathrm{s}$ & es & teachers & Language skills & All of them used \\
\hline \multirow[t]{11}{*}{10} & 7 & have more & specially spelling, & computer software in \\
\hline & & than 5 years & memorization & teaching. \\
\hline & & of & skills, phonics, & Most of them (99\% like \\
\hline & & experience & reading & to use iPad application in \\
\hline & & & comprehension & teaching. \\
\hline & & & and handwriting. & Most of them (95\%) \\
\hline & & & & heard about iPad \\
\hline & & & & applications, useful \\
\hline & & & & features used in learning \\
\hline & & & & applications for children \\
\hline & & & & with dyslexia. \\
\hline
\end{tabular}

Most educators (over 90\%) conceded to the significance of innovation and of iPad use for showing students with dyslexia. In light of their data, the researcher began conceptualizing on the best way to develop and what sort of utilization to incorporate into the iPad program to assist the students with dyslexia enhancing their spelling, reading and writing aptitudes in EFL.

\section{IPad Implementation}

The experimental group had 45 minutes for using of iPad in the course of each English period. Only the experimental groups had access to the English skills app. The researcher confirmed this by downloading all of the general reading, spelling and 
writing apps on his own iPad and checking them thoroughly for inclusion of note reading. The researcher borrowed (10 iPad) for the study from school. This was an applicable number since there were no more than 10 students at a time in the experiment group. Student's seemed excited to try the iPad. The researcher had downloaded 10 games for the students in the experimental groups to use during iPad time. The researcher downloaded the apps (reading, writing and spelling) on each iPad. The students in the experimental group have worked on the nominated app. Since there were no more than 10 students in the group, the researcher was capable of monitoring the students in the group to make sure they did what essential to in front of him. There is an aural component to the guided-practice app. The tones are sounded simultaneously with a child's voice saying the name of each word. The researcher gave initial instruction for the each skill app to the group and had the students started to practice the program with my help and instruction. Students in the experiment group quickly became involved in the app and were very interested in moving through the levels. Students moved through the levels at their own pace and were able to repeat the exercises in each level as many times as they felt necessary to learn the material. This supported the concept of over learning that was shown to be effective in Nicolson and Fawcett's theory (1990) of automaticity, Automaticity is often defined as processing without attention. Attention is necessary to support initial performance, but gradually with practice, the need for attention diminishes, until ultimately performance can proceed without attention (LaBerge \& Samuels, 1974; Logan, 1978; Posner \& Snyder, 1975; Shiffrin \& Schneider, 1977).

The researcher noticed that students in the experimental group enjoyed the use of the iPad and responded positively to its multisensory capabilities. Such capabilities included the way they could move images on the screen with their fingers and manipulate the size of images or words on the screen by the swiping of the thumbs and fingers. Students also had fun trying the different games. They especially liked the ones that included different levels of play so they could challenge themselves and 
each other to reach higher levels. The iPad apps had chosen carefully to enhance students 'reading, writing and spelling skills and help them in the intended course. These apps were arranged and numbered so students could find their way to their iPad and use the same one for every session. The app is designed in such a way that students may always repeat and review levels of learning. The researcher cleaned all iPad screens with a antiseptic wipe after each period. Students accustomed well to the routine of each iPad period. They were able to get over the excitement of having an iPad to use and would quickly become quiet at the opening of each period to listen for my instructions. The experimental group was able to work their way through different levels of intended apps for spelling, reading and writing skills.

\section{The criteria of Program's iPad Applications}

The multisensory applications utilized as a part of the examination were created by the researcher and empowered the students with dyslexia to utilize the greater part of their faculties, for instance, to hear, see, and contact the music notes, enabling them to rehearse for automaticity. Also, the applications picked were predictable with the prescribed criteria for the determination of instructional norms by ADEC (Roblyer and Doering, 2010). The instructional applications had engaging configurations and exercises, with levels coordinated to the abilities of the students with dyslexia. Likewise, the applications were inspected for their instructional esteem so "... students will be inspired instead of disappointed by the exercises" (Roblyer and Doering, 2010, p. 92), mulled over any "... social, societal, and social... " suggestions (Roblyer and Doering, 2010, p. 92). The applications decided for the guided-rehearse practices on the iPad met the majority of the ADEC's criteria for what is viewed as great instructional programming. The applications were appealing and understudies could propel their level contingent upon their capacities on reading, writing, and spelling. students were spurred to advance through the distinctive levels by remarks that showed up on the screen. The 3 applications were 
instructive and included parts of educating the English aptitudes under scrutiny. For instance, a part of the applications enables students to utilize their faculties to learn. students may pick the applications which they like to begin with or may pick their extra diversions which likewise proposed to improve learning. The applications were created by the specialist and joined both coordinated (objectivist) and constructivist methods for learning in that it is a guided-hone task that additionally gives pathways to students to build up their scholarly aptitudes more distant through the investigation of various approaches to spell, read and write. The researcher assessed the substance legitimacy of the applications through expert instructors who show students at an indistinguishable school from these applications are coordinating are appropriate for students 'ages, the substance of the mediation test and clear. This included reading tunes of their decision and playing alongside instructive applications. "Programming in light of constructivist thoughts enables the client to get some importance from the experience of utilizing it, which isn't regularly a consequence of penetrating and-practice programming" (Dorfman, 2006).

Table 2: Applications used in the iPad program for the students with dyslexia

\begin{tabular}{|c|c|c|c|}
\hline $\begin{array}{l}\text { Target } \\
\text { Skills }\end{array}$ & $\begin{array}{c}\text { Applicati } \\
\text { ons }\end{array}$ & Description & How to play \\
\hline Spelling & $\begin{array}{l}\text { Simplex } \\
\text { Spelling } \\
\text { Phonics } \\
\text { English }\end{array}$ & $\begin{array}{lr}\text { Improves } & \text { English } \\
\text { spelling and reading } \\
\text { skills by using a powerful } \\
\text { combination of phonics } \\
\text { lessons, spelling / word } \\
\text { patterns, our unique } \\
\text { "reverse } \\
\text { approach phonics" } \\
\begin{array}{lr}\text { contextually } \\
\text { spelling rules. }\end{array}\end{array}$ & $\begin{array}{l}\text { Guides the student and acts as } \\
\text { a personal spelling coach with } \\
\text { every word, while teaching } \\
\text { "how to spell" English words. } \\
\text { - not only teach a list of } \\
\text { words, but to teach students } \\
\text { "how to spell" these words. } \\
\text {-have a higher level of } \\
\text { literacy than students who } \\
\text { learn to read by using flash } \\
\text { cards and the whole word } \\
\text { approach. Also that not all } \\
\text { readers are good spellers, but } \\
\text { almost all good spellers are } \\
\text { also good readers. }\end{array}$ \\
\hline
\end{tabular}




\begin{tabular}{|c|c|c|c|}
\hline JRCIET & & Vol. 4 , №. 3 & July 2018 \\
\hline Writing & $\begin{array}{l}\text { Jumbled } \\
\text { Sentences }\end{array}$ & $\begin{array}{l}\text {-is a series of five free } \\
\text { iPad apps designed to } \\
\text { help students learn to } \\
\text { construct sentences. } \\
\text { - drag and drop activities } \\
\text { in which they sort } \\
\text { jumbled words into } \\
\text { sentences. } \\
\text {-When students correctly } \\
\text { create sentences they } \\
\text { earn virtual coins that } \\
\text { they can then use to buy } \\
\text { virtual stickers to mark } \\
\text { their progress. }\end{array}$ & $\begin{array}{l}\text {-The students put the parts in } \\
\text { order to form a sentence. } \\
\text {-They tap on 'OK' to check } \\
\text { their answer. Students earn } \\
\text { one coin for each correct } \\
\text { answer. If they get stuck, they } \\
\text { tap on 'Hint' and use one coin } \\
\text { to find out the next correct } \\
\text { part. } \\
\text { They play as fast as you can } \\
\text { to level up. The more coins } \\
\text { they collect, the more hints or } \\
\text { stickers they can get. } \\
\text { They can design their own } \\
\text { sticker page with the colorful } \\
\text { stickers. }\end{array}$ \\
\hline Reading & $\begin{array}{l}\text { The } \\
\text { Visual } \\
\text { Reading } \\
\text { App }\end{array}$ & $\begin{array}{l}\text {-assists those with } \\
\text { Dyslexia, or individuals } \\
\text { who have difficulty } \\
\text { reading words. }\end{array}$ & $\begin{array}{l}\text {-The students need to place } \\
\text { images or videos above each } \\
\text { word. } \\
\text { They have fun adding their } \\
\text { own concrete nouns for } \\
\text { everyday common objects } \\
\text { that they are familiar with. - } \\
\text { For some abstract words the } \\
\text { students are encouraged to } \\
\text { find images or make videos } \\
\text { that are familiar with. }\end{array}$ \\
\hline
\end{tabular}

\section{The Spelling Skills Test}

A spelling test intended to check the students' with dyslexia capacity to spell words with short and long vowels, which incorporated into the students' results records. The motivation behind this accomplishment test was to gauge the students' capability to spell words well. The test would be contained 12 items. The test would take 40 minutes. All things in the test were comparable to what incorporated into ADEC's syllabus (results). 
Table 3: The Spelling skills test

Skill

$$
\text { Spelling }
$$

\section{Test description}

1- Short a (a):

2- Short o (o):

3- Short I (i):

4- Short u (u):

5- Short e (e):

6- Long a (a_e):

7- Long a (ai):

8- Long a (ay):

9- Long o (o_e):

10- Words with (sh):

11- Words with (th):

12- Words with (ck):

\section{The Writing Skills Test}

In the writing test, the students would answer Jumbled Sentences which intended to enable students to figure out how to build sentences. The test gave students intuitive exercises in which they sort confused words into sentences. The sound could be turned off in each application. At the point when the sound was turned on students could hear the words read them by the storyteller. The storyteller likewise read the sentences that students build. The test gave students quick criticism on every one of the sentences that they worked to stamp their advance.

Table 4: The Writing skills test

Skill

Writing

\section{Test description}

(jumbled sentences)

Drag the words into the correct boxes and make a correct sentence.

\section{The Reading Skills Test}

The reading test included 5 items, i.e., phoneme blending, phoneme segmentation, phoneme deletion, phoneme manipulation and reading real words. These diverse things had picked carefully to agree with the courses of English at school and with the participation of educators at school. These shifted things to give both the researcher and students an opportunity to assess and evaluate the students' capacities in reading ability. All 
items in the test were identical to what incorporated into ADEC's syllabus (results).

Table 5: The Reading skills test

Skill

Reading

\section{Test description}

1- Syllable Deletion

2- Phoneme Categorization

3- Phoneme Blending

4- Phoneme Segmentation

5- Phoneme Deletion

6- Phoneme Manipulation

7- Nonsense Words and Real Words

This test contained three aptitudes, i.e. spelling, composing and perusing would be utilized as a part of assessing understudies' vocabulary change in the grade school would be utilized as the significant instrument in this examination. The scientist worked with understudies so as to enhance their perusing, composing and spelling abilities and not just one aptitude as they are coordinated abilities and impact on each other (Chamot and O'Malley, 1994). Also, understudies have learned Math and Science by utilizing English Language and as indicated by ADEC Policy In Cycle 1 reviews, the dialect of the guideline will contrast by subject. English Medium Teachers (EMTs) will give direction in English Language, Mathematics, and Science (Policy Manual 2012-2013 P-12).that's the reason the researcher utilized the three fundamental abilities of reading, writing and spelling as a stage to enhance these aptitudes which will help students in English Language as well as with Science and Mathematics subjects. The reason for this accomplishment 
test was to assess the students 'upgrades as the researcher would adjust the test and would explore its legitimacy and unwavering quality heretofore. A pretest would be held toward the start of the third semester. All items in the test were determined in the students' results reports and its norms and in the meantime on iPad applications. The vast majority of the dialect utilized as a part of the test would incorporate spelling, writing and reading practices learned in earlier years' course readings and also the objective things in the test .

The posttest would be held two months after the fact which is the period dispensed for the entire course scope. Along these lines, there would be no damage to students' accomplishment as the instructor would take after the timetable and directions of the school. The investigation would be done amid the students' timetable.

\section{The Scoring System}

The researcher utilized a pretest-posttest with the criteria of the students' benchmarks report as takes after; Mastered, Developed, Emerging and Not accomplishing. The educator would tick under the face which suited students' reactions (Mastered= 3 marks, Developed=2 marks, Emerging=1 check, Not achieving $=0$ stamps) as indicated by the season of the test.

\section{Research Design}

\section{The philosophical paradigms and my methodological choices}

With a specific end goal to indicate what The researcher chose was the most proper methodological approach for this exploration, the thoughts, and destinations of two principles inquire about ideal models - the positivist and interpretive/constructionist common in extraordinary necessities look into are underlined. This is imperative as the basic leadership process when moving toward look into relies upon the worldview which is taken after (Avramidis and Smith, 1999:27). The accompanying table analyzes the two ideal models. 
Table 6: Comparing the two paradigms

Positivism

Interpretivism

Underlying

assumptions

about:

Discover laws and generalizations which explain reality and allow predict and control
To understand and interpret daily occurrences and social structures as well as the meanings people give to the phenomena
Purpose(s) of research
Single, givens, fragmentable,

Multiple, constructed through tangible, measurable, convergent human interaction, holistic, divergent

Events are explained based on knowable facts, real causes or simultaneous effects; lawlike regularities exist

Events are understood through mental processes of interpretation influenced by and interacts with social context-mutual simultaneous shaping

Independent, dualism

Interrelated, dialogic

Relationship between the knower and the known

Positivism: The positivist paradigm of phenomena as free substances and quantifiable factors unaffected by the presence of other phenomena can't speak to their dynamic and social character. Positivists contend that the motivation behind taking a gander at phenomena deductively is to build up causal clarifications for social phenomena (Schwandt, 2000:190). The positivist worldview tends to utilize quantitative procedures, which assume a particular hypothesis from which particular cases are drawn. Hypothetical suspicions are created before the start of the examination, and decide the sort of information required to test them; 'the beforehand gained learning is substantiated as an extended and affirmed paradigm' (Markova, 1996:181).

Interpretivist/constructivist: the researchers contend that the truth is subjective and has different implications which individuals develop through their activities in the social world. It 
is important to comprehend human activity and members in research ought to be permitted to consider the phenomena under examination and follow up on them (Robson, 1993). The interpretive approach studies 'the individual [through] little scale, non-measurable research, deciphering the particular; the researcher had a functioning individual inclusion and manages 'smaller scale ideas: singular viewpoint, individual develops, arranged implications, meanings of circumstances' (McKenzie, 2001:17).

\section{Design}

The impacts of iPad mediation program on students' with dyslexia aptitudes were contemplated utilizing both qualitative and quantitative techniques to empower an all-encompassing and profound comprehension of how their abilities are enhanced and what noteworthy others around them recognize as their shortcomings and qualities in utilizing the iPad program .

A mixed technique configuration utilized as a part of the request to acquire rich information about the members' reading, spelling and writing improvement; in which various instruments are required .

The reason for leading the multi-strategy configuration is to help the quantitative information by giving inside and out subjective data to the more rich comprehension of the quantitative outcomes. This technique for investigating is titled as mixed method strategy outline which Creswell (2012) recognized it as a plan "to gather quantitative and subjective information simultaneously or serially, yet to have one type of information assume an accommodating part to the next type of information" (p. 544).

\section{The iPad Program's Data Analysis}

The information from the spelling, composing and perusing pre and post evaluations estimated the impact of the iPad program on the students' with dyslexia change in light of normal gathering scores. The individual aftereffects of the electronic and the paper-based appraisals were analyzed over the two 
gatherings. The data would likewise note with reference to how students scored on an individual premise to decide the effect of the iPad on spelling, writing and reading improvement. The test utilized for the investigation of the pre and posttest quantitative information was the Mann Whitney U test. This test was chosen on the grounds that The Mann-Whitney $U$ test invalid theory (H0) determines that the two gatherings originate from a similar populace. In different terms, it requests that the two free gatherings are homogeneous and have a similar dissemination. Leverage with this test is that the two examples under thought may not really have a similar number of perceptions. It manages little examples that for the most part incorporate under 15 members (Kazdin 2003).

Table 7: Results of the Mann Whitney U Test Comparing the Groups' Pretest Academic Achievement Scores

\begin{tabular}{|c|c|c|c|c|c|c|c|c|}
\hline $\begin{array}{c}\text { Significance } \\
\text { level }\end{array}$ & $\begin{array}{c}\text { Valu } \\
\text { e of } \\
U\end{array}$ & $\begin{array}{c}\text { Sum } \\
\text { of } \\
\text { Ranks }\end{array}$ & $\begin{array}{c}\text { Mea } \\
n \\
\text { Ran } \\
k\end{array}$ & $\begin{array}{c}S t d . \\
\text { Deviati } \\
\text { on }\end{array}$ & $\begin{array}{c}M e a \\
n\end{array}$ & $N$ & Groups & Test Domains \\
\hline not & 0.22 & 68.5 & 6.8 & 0.873 & 4.2 & 10 & control & Spelling \\
\hline $\begin{array}{l}\text { statistically } \\
\text { significant }\end{array}$ & & 68.5 & 6.8 & 0.875 & 4.1 & 10 & $\begin{array}{c}\text { experime } \\
\text { ntal }\end{array}$ & \\
\hline & 0.11 & 64 & 6.4 & 1.154 & 6.8 & 10 & control & Writing \\
\hline $\begin{array}{l}\text { statistically } \\
\text { significant }\end{array}$ & & 64 & 6.4 & 1.159 & 8.7 & 10 & $\begin{array}{c}\text { experime } \\
\text { ntal }\end{array}$ & \\
\hline not & 0.07 & 69 & 6.9 & 1.370 & 7.1 & 10 & control & Reading \\
\hline $\begin{array}{l}\text { statistically } \\
\text { significant }\end{array}$ & & 69 & 6.9 & 1.370 & 6.9 & 10 & $\begin{array}{c}\text { experime } \\
\text { ntal }\end{array}$ & \\
\hline
\end{tabular}

An examination of the findings in Table 7 reveals the results of Mann Whitney $U$ test for the pretest academic achievement scores of the students in the experimental and control groups did not show any statistical difference where the value of $(\mathrm{U})$ that reflects the differences between the two groups, respectively, is $(0.22),(0.11),(0.07),(0.49)$, and $(0.30)$, The rank average of the pretest scores of the experimental group and control group students was as follows;(6.8),(6.4), and (6.9). The same rank averages of the groups' pretest academic achievement scores indicate that before the intervention program for the 
experimental group, the experimental and control groups had somewhat equal pretest academic achievement levels.

The following table indicates the results of the experimental group after the intervention program.

Table 8: Results of the Mann Whitney U Test to Compare the Groups' Post test Academic Achievement Scores

\begin{tabular}{ccccccccc|c}
$\begin{array}{c}\text { Level } \\
\text { of } \\
\text { signific }\end{array}$ & $\begin{array}{c}\text { Value } \\
\text { of } u\end{array}$ & $\begin{array}{c}\text { Total } \\
\text { of } \\
\text { ance }\end{array}$ & $\begin{array}{c}\text { Mean } \\
\text { ranks }\end{array}$ & $\begin{array}{c}\text { SD } \\
\text { ranks }\end{array}$ & & $\begin{array}{c}\text { me } \\
\text { an }\end{array}$ & $\begin{array}{c}\text { Student } \\
\text { number }\end{array}$ & Groups & $\begin{array}{c}\text { Test } \\
\text { domains }\end{array}$ \\
0.05 & 2.076 & 140.5 & 14.15 & 1.059 & 5.7 & 10 & Experimental & spelling \\
& & 68.5 & 6.8 & 0.873 & 4.2 & 10 & Control & \\
0.01 & 3.099 & 146 & 14.6 & 0.707 & 8.5 & 10 & Experimental & writing \\
& & 64 & 6.4 & 1.159 & 6.7 & 10 & Control & \\
0.01 & 2.721 & 141 & 14.1 & 1.197 & 8.9 & 10 & Experimental & Reading \\
& & 69 & 6.9 & 1.370 & 7.1 & 10 & Control &
\end{tabular}

The outcomes demonstrated that, there is a presence of factual critical contrasts of the Ranks normal evaluations of the experimental group and the Ranks normal evaluations of the control group in the post-test on the dimensional estimation on dyslexia test, where the estimation of $(\mathrm{u})$ for the domains of the spelling (2.076) and composed execution (3.099), and Reading (2.721), and that measurably huge contrasts at the level (0.05), while the estimation of $(\mathrm{u})$ for all areas of the post-test is measurably huge at the level of (0.01) for the advantage of students of the experimental group.

\section{Conclusion}

The iPad is not just a consumption tool, unlike other handheld devices, but it is also meant for easy and socially viable creation and presentation of new ideas and content (Walters, 2011). Existing studies have shown that the iPad is very effective at concept presentation and can also be used as a demonstrator for classroom material; however, the iPad's contributions to educational literacy and learning are still unknown because of the absence of thorough empirical studies (Timmermann, 2010). 
It has been claimed that traditional educational systems meet challenges to respect the ever-changing needs and requirements of young children of today's generation (Timmermann, 2010). A modern education system is one in which new forms of pedagogy and instructional strategies are implemented in a way that does not see students as recipients of information only but instead as active participants' who decode information actively and engage in fruitful discussion with peers and teachers.

The ultimate goal of this form of pedagogy and instruction is to support and reflect students' learning so that their needs and expectations are understood and met (Timmermann, 2010).

The overwhelming benefits of the use of technology with dyslexic students are motivation, and engagement in learning. The previous studies work to prove the claim made by (Barone \& Wright, 2008). Each experience indicated how the use of technology encourages reluctant readers to re-engage in a new and exciting way. The ability for technology to make texts accessible in new ways through the adjustment of font sizes and layouts are also valuable advantage (Barone \& Wright, 2008, p. 302). The multiple benefits of using iPad technology were taken into consideration when designing the applications for the iPad program used in the current study. Based on the objectives of the current study, Technology motivates and encourages - Students that are otherwise disengaged when it comes to reading traditional print books are excited when the reading material is presented in an electronic form. Technology gives student's responsibility and choice in what they read - By allowing students the choice to read what they like on an electronic device and making it accessible through font size or text to speech functions, educators are driving authentic reading experiences. Students are encouraged to be self-regulating (Barone \& Wright, 2008, p. 302) - Reading on an electronic device is an overwhelmingly private experience, no-one can see what the student is reading. Students make choice on what they want to read based on their own opinions - not the peer pressure exerted from others. 


\section{Reference}

Avramidis, E, \& Smith, B. (1999). An introduction to the major research paradigms and their methodological implications for special needs research. Emotional and Behavioural Difficulties. 4. 27-36. 10.1080/1363275990040306.

Barone, D., \& Wright, T. (2008). Literacy Instruction With Digital and Media Technologies. The Reading Teacher.

Beech, John \& Singleton, Chris (1997). _The Psychological Assessment of Reading_. Routledge

Bramlett, R. K., Murphy, J. J., Johnson, J., \& Wallingsford, L. \&. (2002). Contemporary practices in school psychology: A national survey of roles and referral problems. Psychology in the Schools.

Chamot, A. U., \& O'Malley, J.M. (1994). "The CALLA handbook: Implementing the cognitive-academic language learning approach." Reading: MA: Addison Wesley.

Creswell, J. W. (2012). Qualitative inquiry \& research design: Choosing among five approaches (4th ed.). Thousand Oaks, CA: Sage.

Dorfman, J. (2006). Learning music with technology: the influence of learning style, proir experiences, and two learning conditions on success with a music technology task. Doctoral Dissertation.

Fawcett, A. J., \& Nicolson, R. I. (1994). Naming speed in children with dyslexia. Journal of Learning Disabilities, 27, 641-646.

Kazdin AE. (2003). Research Design in Clinical Psychology. Needham Heights, MA: Allyn\& Bacon. 4th ed.

LaBerge, D., \& Samuels, S.J. (1974). Toward a theory of automatic information process in reading. Cognitive Psychology, 6, 293323.

LOGAN, JR. (1978). "Theory of analytic modulation systems," The. Bell System Technical Journal, 57(3), 491-576. 
Lundberg, C. , Elderman, J. L., Ferrell, P. and Harper, L. (2010), Data gathering and analysis for needs assessment: A case study. Perf. Improv., 49: 27-34.

Marková, I, (1996). Towards an epistemology of social representations.Journal for the Theory of Social Behaviour 26 (2):177-196.

McKenzie, J. A. (2001), Challenges for science education and research in Australia. Clinical and Experimental Optometry, 84: $255-257$.

Mullis, I., Martin, M., Kennedy, A., \& Foy, P. (2007). IEA's study of reading literacy achievement in primary schools. Boston: Boston College.

Posner, M. I., \& Snyder, C. R. R. (1975). Attention and Cognitive Control. In R. L. Solso (Ed.), Information Processing and Cognition (pp. 55-85). Hillsdale, NJ: Erlbaum.

Roblyer, M., \& Doering, A. (2010). integrating educational technology into teaching (5th ed). Boston: Person Education.

Robson, C., (1993). Real world research: a resource for social scientists and practitioner researchers.

Schneider, E. (2009). Dyslexia and foreign language learning. The Routledge Companion to Dyslexia. . NY: Routledge.

Schneider, W., \& Shiffrin, R. M. (1977). Controlled and automatic human information processing: I. Detection, search, and attention. Psychological Review, 84(1), 1-66.

Schwandt, Thomas. (2000). Three Epistemological Stances Three Epistemological Stances for Qualitative Inquiry for Qualitative Inquiry.

Timmermann, P,. (2010) : "Is my iPad in my backpack?” Journal of Digital research \& publishing, University of Sydney.

Walters, E,. (2011) "Will the iPad revolutionize education?" 
